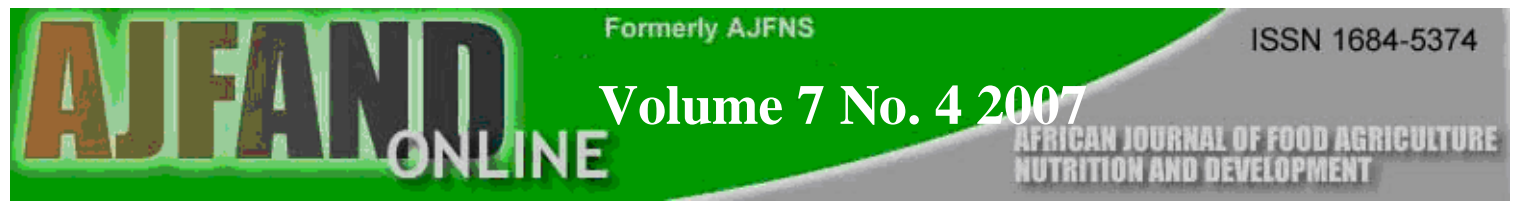

\title{
Conservation of African Leafy Vegetables in South Africa
}

\section{By}

Jansen van Rensburg Willem ${ }^{* 1}$, Voster Ineke H.J. ${ }^{1}$, Van Zijl J.J.B. ${ }^{1}$ and L. Venter Sonja ${ }^{1}$

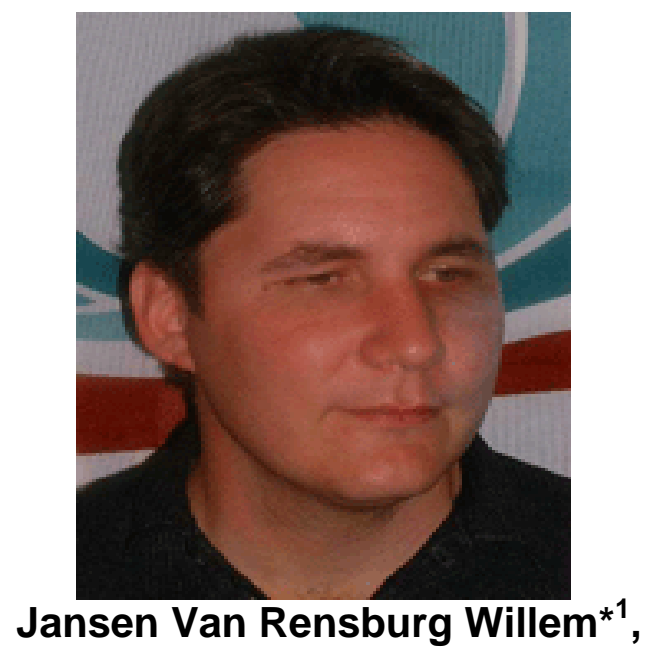

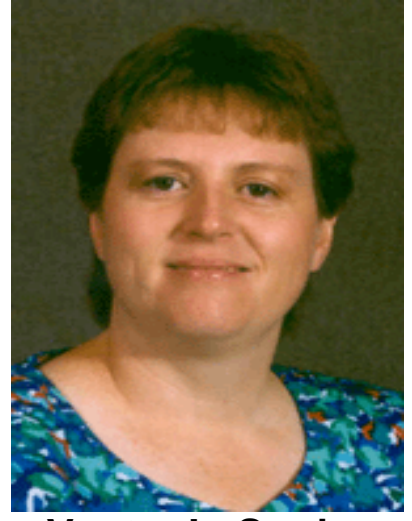

Venter L. Sonja

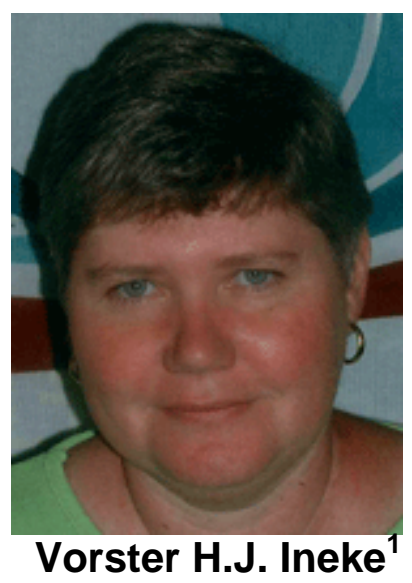

Vorster H.J. Ineke ${ }^{1}$

*Corresponding author Email: wivrensburg@arc.agric.za

${ }^{1}$ ARC-Roodeplaat Vegetable and Ornamental Plant Institute,Private Bag x293,Pretoria,0001, South Africa.Tel: + 27128419611 




\section{ABSTRACT}

The nutritional and cultural importance of African Leafy Vegetables has become very important in South Africa in the past few years. Recent research has also confirmed these issues, leading to the incorporation of African Vegetables into the core business of the ARC. ARC-Roodeplaat wants to improve the distribution and conservation status of African Leafy Vegetables. Geographical collection data on Amarant, Cleome gynandra, Corchorus olitorius and Vigna inguiculata was obtained from the National Botanical Institute and the data was analyzed with DIVA and Flora map. Ecogeographical distribution maps were drawn to predict the possible distribution of the species. Germplasm of African Leafy Vegetables was collected during routine visits and the conservation status was discussed with participants in the study areas of Arthurstone in Bushbuckridge, Watershed near Ladysmith and Mars/Glenroy near Polokwane. Germplasm of various species were also collected in collaboration with the Plant Genetic Resource Centre (NPGRC) of the Department of Agriculture in Arthurstone and Watershed.

The NPGRC included leafy vegetables in their mandate since this trip. Seed flow diagrams were used to discuss the Watershed community's seed exchange systems. It was clear when discussing African leafy vegetables in communities that their conservation and utilization are declining. Also looking at the trendlines of African Vegetables availability and utilization it is clear that the use and availability of African Leafy vegetables are declining due to various reasons. Two major reasons are the negative image of the African Leafy Vegetables and the increased use of "exotic" vegetables like spinach and carrots. The active promotion, use and conservation of African Leafy Vegetables are important if we want to increase the production potential and potential contribution towards food security in South Africa. This will ensure that the status of these crops is enhanced, specifically their contributing towards sustainable nutrition as well as sustainable production. Results from promotion activities in the project (reported in another paper) indicated that the negative image of African Leafy Vegetables could be reversed and also had an affect on the roll-out of the project to other areas of research such as plant protection, nutritional analysis and food safety, crop science and indigenous knowledge systems.

Key Words: Ecogeographical, Conservation, Leafy vegetable 


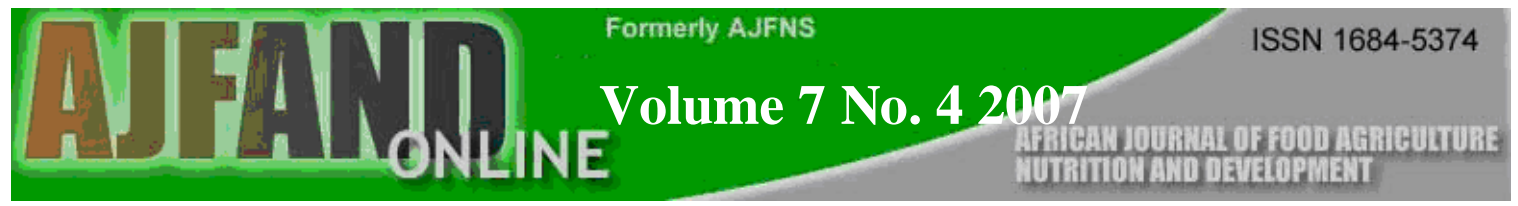

\section{INTRODUCTION}

For centuries African Leafy Vegetables (ALVs) were part of the daily livelihood of the African people. Unfortunately, it was taken for granted and the people believed that it will always be part of their live as it was growing wild and harvested for free. Old ladies who passed the responsibility and knowledge on to younger generations safeguarded seed of certain species. Unfortunately, due to various social, political and economical reasons these systems do not exist in many places any more. As part of a project funded by the International Plant Genetic Resource Institute (IPGRI), the Agriculture Research Council Roodeplaat Vegetable and Ornamental Plant Institute (ARC-Roodeplaat) investigated the distribution and conservation status of certain ALV species in South Africa.

\section{Ecogeographical study}

An ecogeographical investigation of Amarant, Chenopodium album, Cleome gynandra, Vigna unguiculata and cucurbits was carried out. Geographical collection data were obtained from herbarium sheets of the National Botanical Institute in Pretoria, South Africa. A total number of 1446 entries, collected between 1877 end 2000, were extracted from the Pretoria Computerized Information System (PRECIS). These collections were done in South Africa, Botswana, Namibia, Swaziland and Lesotho. The grid references, of some entries, were given in the following format $3318 \mathrm{CD}$. It indicated a specific square south east of the intersection of $18^{\circ} \mathrm{E}$ and $33^{\circ} \mathrm{S}$ as indicated in Figure 1.

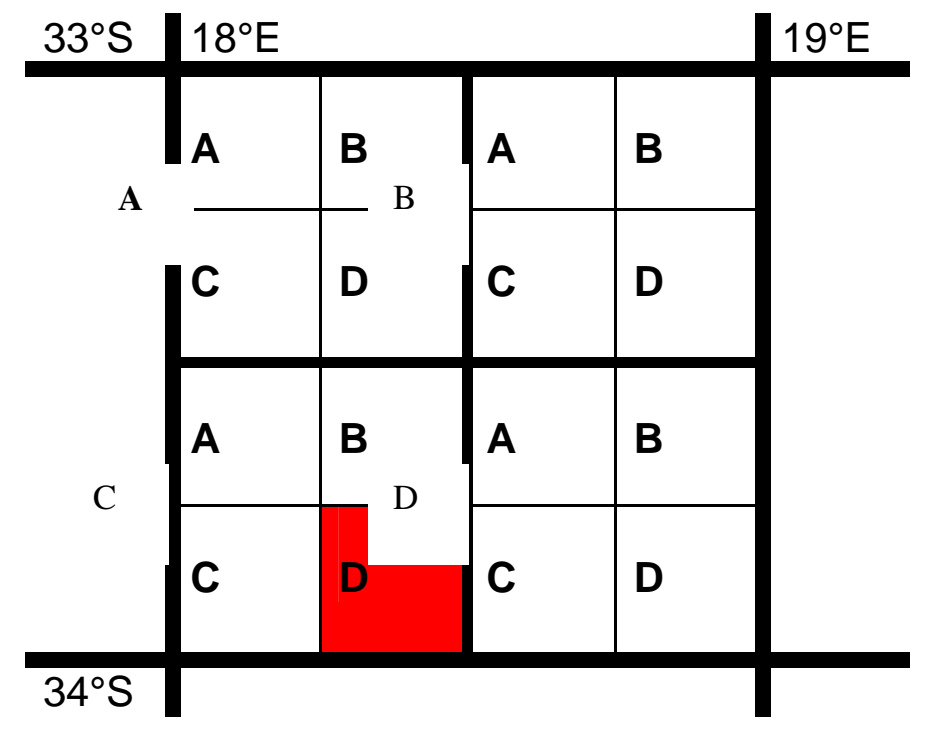

Figure 1: The location of $3318 \mathrm{CD}$ 




These grid references, of the point in the centre of each of the 16 squares, are converted to decimal fractions in table 1. Thus $3318 \mathrm{CD}$ will be converted to $33.875^{\circ} \mathrm{S}$ and $18.375^{\circ} \mathrm{E}$.

The data were converted to DBASE using DIVA [1]. Distribution maps of the collection sites were drawn with the DIVA as well. Predictions of diversity and distribution were made with FloraMap. All the entries of a specific group were clustered together in one group, using Wart analysis, and these groups were used in the probability analysis to predict the possible distribution of the different groups.

\section{Amaranthus spp (Amaranthaceae)}

A total of 469 entries of Amaranthus spp. were considered (Appendix 1).

A. thunbergii (159 entries)

A. spinosus (62 entries)

A. deflexus (47 entries)

A. hypochondriacus

A. viridus (27 entries)

A. hybridus subspecies - (A. hybridus subsp. cruentus - 19 entries: A. hybridus subsp. hybridus var. erythrostachys - 18 entries, A. hybridus subsp. hybridus - 158 entries)

Amaranthus spp are normally wild and weedy, growing widespread in southern Africa except in the more arid south-western areas as seen in figure 2. It is not widely cultivated but is collected in the wild and in cultivated fields.


Figure 2 a. Distribution of the sites where Amaranthus spp. were collected. b. Predicted distribution of the mentioned Amaranthus spp in Southern Africa as predicted by Floramap. 




\section{Chenopodium album (Chenopodiaceae)}

Chenopodium album (181 entries)

Chenopodium is a wild weedy plant collected by the women in the fields all over South Africa. There is no evidence that Chenopodium is cultivated in south Africa. It is widely distributed but is more prevalent at higher altitudes (Figure 3).

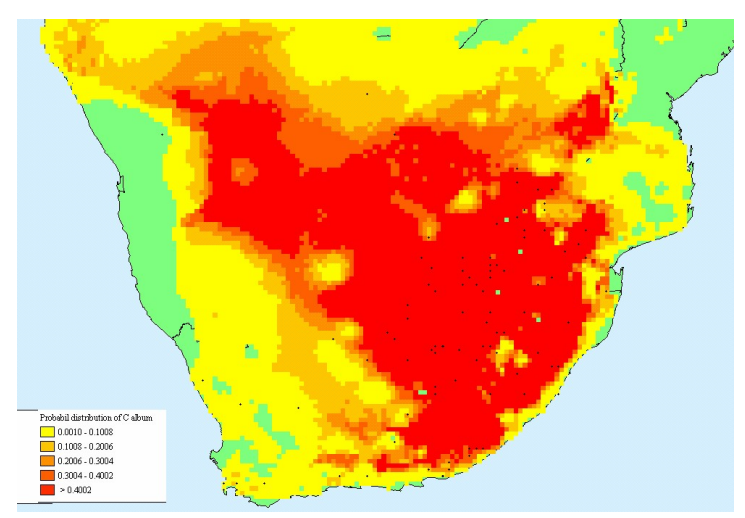

Figure 3 a. Distribution of the sites where Chenopodium album was collected. $\mathbf{b}$. Predicted distribution of Chenopodium album in southern Africa as based on map drawn by

Floramap

\section{Cleome gynandra (Gynandra gynandrum) (Capparaceae)}

Cleome gynandra (184 entries)

Cleome gynandra is mostly a wild weedy plant collected by women in the fields in the northern parts of South Africa. . It is unknown in KwaZulu-Natal although some plants were collected there (Figure 4). There is no evidence that Cleome is cultivated in South Africa. 

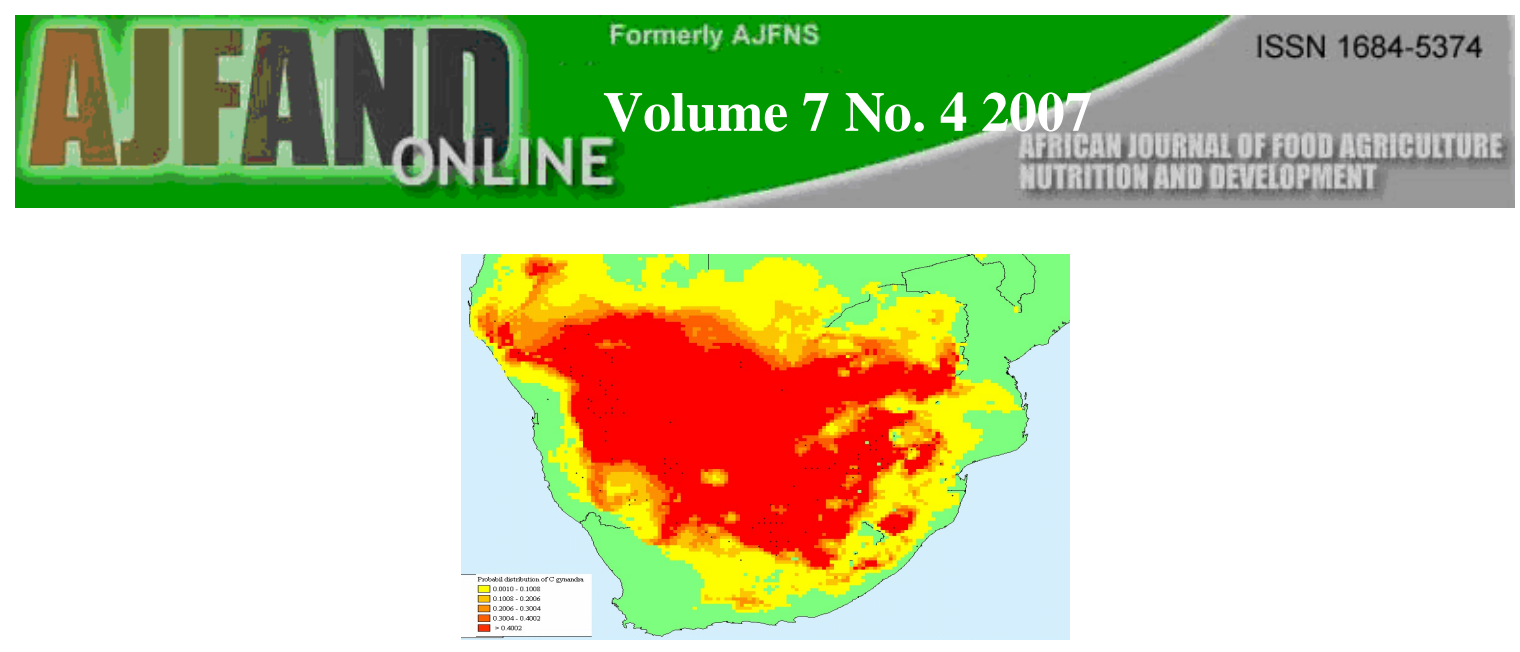

Figure 4 a. Distribution of sites where Cleome gynandra were collected in Southern Africa. b. Predicted distribution of Cleome gynandra in Southern Africa based on by Floramap.

\section{Vigna unguiculata (Fabaceae)}

Vigna unguiculata subsp. dekindtiana var. dekindtiana (45 entries)

Vigna unguiculata subsp. dekindtiana var. huillensis (14 entries)

Vigna unguiculata subsp. protracta (23 entries)

Vigna unguiculata subsp.stenophylla (82 entries)

Vigna unguiculata subsp. tenuis var. ovata (1 entry)

Vigna unguiculata subsp. unguiculata (236 entries)

Cowpeas (Vigna unguiculata) are cultivated for dry beans in various areas in South Africa. It is also found in the wild in the eastern areas of KwaZulu-Natal, Mphumalanga and the Limpopo province (Figure 5).



Figure 5 a. Distribution of the collection sites of Vigna unguiculata. b. Predicted distribution of the mentioned Vigna unguiculata subspecies in Southern Africa as based on map drawn by Floremap. 


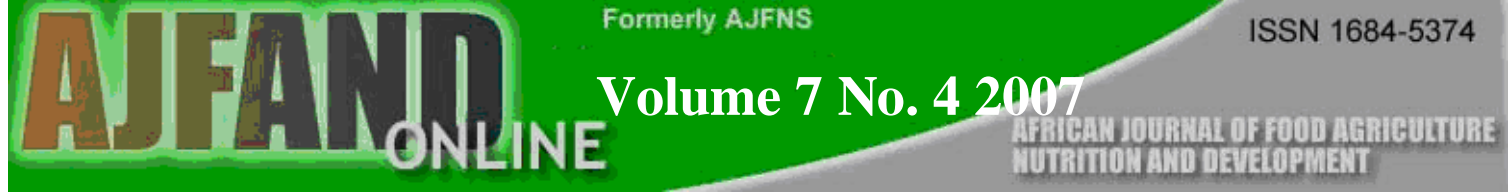

\section{Cucurbit leaves}

Citrillus lanatus (167 entries) and

Citrillus rehmii (13 entries)

Pumpkins, melons and squash (Cucurbita maxima, C. pepo and C. moschata) are widely cultivated in South Africa for their fruit and by some farmers for the leaves. Leaves of all cucurbits are used for leafy vegetables. The collections are from species that grow in the wild in the more arid areas of western and central southern Africa (Figure 6).



Figure 6 a. Distribution of sites where Citrillua lanatus and C. rehmii were collected in Southern Africa.. b. Predicted distribution of Citrillus lanatus and C. rehmii based in map drawn by Floramap.

\section{COLLECTION}

A collection trip in collaboration with the National Gene bank (National Department of Agriculture) was undertaken during May 2002. Two hundred and twenty five accessions were collected (Table 2) in Arthurstone (an area within Bushbuckridge), Watershed near Ladysmith and Mars/Glenroy near Polokwane. Only the local names of certain accessions are known and these accessions have to be identified. The base collection of these accessions is stored at the National Gene bank. A working collection will be stored at ARC-Roodeplaat. Material of landraces of other crops not used as leafy vegetables was also collected for the National Gene bank.

The accessions were collected from farmers in the community as seed. The seeds are saved from one season to the other in containers, mostly glass or airtight plastic containers. Ash is added in some instances to discourage pests. 


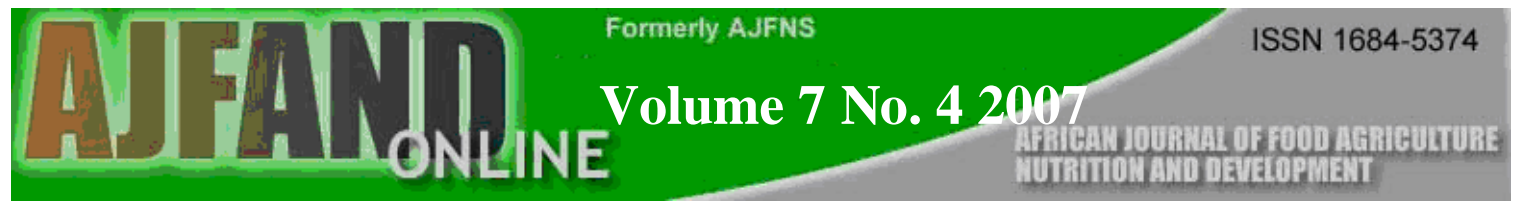

Seed multiplication of selected species was done by ARC-Roodeplaat and the seeds were made available to community members to enhance the availability of seed.

\section{CONSERVATION}

Conservation and seed systems of African vegetables were discussed with the Arthurstone, Mars/Glenroy and Watershed communities. In many areas seed systems are in a poor state. An old lady of high social status used to be the custodian of the seed for the community, but the role has been lost due to various social and economic reasons. The increased significance of "exotic" or "modern" vegetables and the commercial availability of the seed also played a role in the demise of the seed custodians. The community members tend to keep their own seed now or buy from dealers. This leads to scarcity and even loss of some crops that are not part of the formal seed sector. Revival of the role of seed custodians within communities is critical for the conservation and preservation of genetic diversity of the crops that are not part of mainstream seed sector.

The introduction and promotion of "exotic" or "modern" vegetables has had a negative effect on the use of traditional vegetables in communities. The preferences of people have changed to the exotic vegetables, like cabbage. Preparation methods and changing taste preferences of the youth also have a negative influence on the utilization and indirectly conservation of traditional vegetables. Climate and rainfall patterns also have an influence on conservation. Drought led to over harvesting of the plants, thus depleting seed banks. Heavy rains and thunderstorms (especially after droughts) cause to soil erosion and the loss of valuable topsoil as well as the seed in the soil.

\section{THE CASE OF PHARA}

Phara (a local variant of Cucumis melo) is a popular traditional leafy vegetable in the northern parts of South Africa. During discussion with the Mars/Glenroy communities, the ladies realized that it was becoming rather scarce. The ladies decided to collect all the seeds they could in the coming season, and to distribute them to a few other ladies, thus ensuring that the risks were spread. The following season was very dry and unfortunately livestock came into the gardens and all the plants, surviving from the drought, were destroyed, leaving them with no phara. Families from villages nearby were contacted and the phara seed was re-introduced into the community. The community ladies immediately appointed other ladies in each community to look after phara and ensure its survival in the community [2]. 


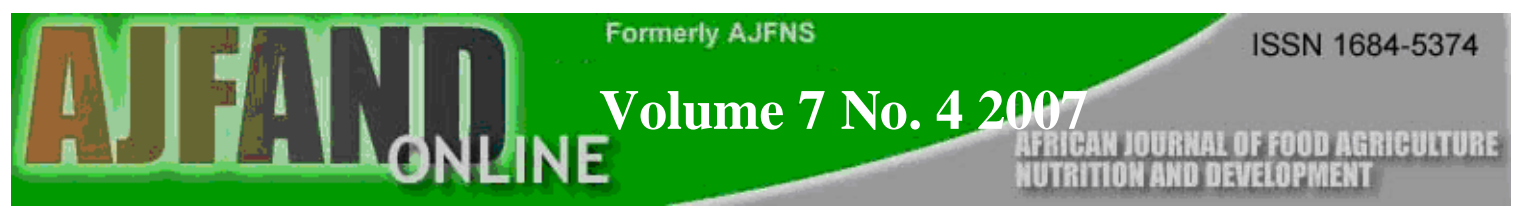

\section{DISCUSSION}

It was clear when discussing African leafy vegetables in communities that their conservation and utilization are declining. The ladies remember that the African leafy vegetables were more abundant during their childhood. Especially the older ladies would say that morogo (the local name for African leafy vegetables collectively) was abundant in their childhood and that they cannot find some of the species any more. The trendlines on the availability and utilization of African Vegetables clearly shows that the use and availability of African Leafy vegetables are declining. Two major reasons for this decline are the negative image of the African Leafy Vegetables and the promotion and increased use of "exotic" vegetables like spinach and carrots.

In South Africa, morogo is regarded is a poor man's food or famine food, especially by the youth. The younger generation of South Africans are used to the taste and textures of the more fatty foods popularized by the media. This perception is, however, changing. Results from promotion activities in the project (reported in another paper) indicated that the negative image of African Leafy Vegetables can be reversed and also had an affect on the roll-out of the project to other areas of research such as plant protection, nutritional analysis and food safety, crop science and indigenous knowledge systems. From the 1960's, modern vegetables like carrots, cabbage, green beans and so forth were actively promoted by agricultural research and extension services.

Crops such as cabbage and spinach have almost completely replaced the African leafy green vegetables in areas where extension was active. Furthermore, extension services actively discouraged the selective weeding practises practised by many farmers and told the farmers to remove the "weeds". The active promotion, use and conservation of African Leafy Vegetables is food security is to be addresses in South Africa. The African leafy vegetables must be promoted as a healthy alternative to the modern vegetables. The African vegetables must also be recognized as an extremely important part of our African heritage. This will ensure that the status of these crops is enhanced, specifically their contribution towards sustainable production and nutrition. The recognition of the role that African Vegetables play in food security and nutrition will also help to increase their conservation status.

\section{CONCLUSION}

In South Africa, morogo is regarded is a poor man's food or famine food, especially by the youth. The younger generation of South Africans are used to the taste and textures of the more fatty foods popularized by the media. 
This perception is, however, changing. Results from promotion activities in the project (reported in another paper) indicated that the negative image of African Leafy Vegetables can be reversed and also had an affect on the roll-out of the project to other areas of research such as plant protection, nutritional analysis and food safety, crop science and indigenous knowledge systems. From the 1960's, modern vegetables like carrots, cabbage, green beans and so forth were actively promoted by agricultural research and extension services. Crops such as cabbage and spinach have almost completely replaced the African leafy green vegetables in areas where extension was active. Furthermore, extension services actively discouraged the selective weeding practises practised by many farmers and told the farmers to remove the "weeds". The active promotion, use and conservation of African Leafy Vegetables is food security is to be addresses in South Africa. The African leafy vegetables must be promoted as a healthy alternative to the modern vegetables. The African vegetables must also be recognized as an extremely important part of our African heritage. This will ensure that the status of these crops is enhanced, specifically their contribution towards sustainable production and nutrition. The recognition of the role that African Vegetables play in food security and nutrition will also help to increase their conservation status.

\section{ACKNOWLEDGEMENT:}

The National Botanical Institute is thanked for the use of data from the National herbarium, Pretoria (PRE) Computerized Information System (PRECIS). 


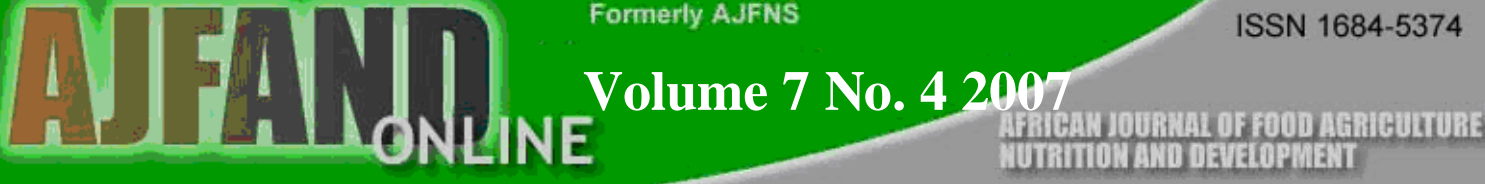

Table 1: Grid references converted to decimal fractions.

$\begin{array}{lll}\begin{array}{l}\text { Grid } \\ \text { reference }\end{array} & \begin{array}{l}\text { Longitudinal } \\ \text { Fraction }\end{array} & \begin{array}{l}\text { Latitudinal } \\ \text { fraction }\end{array} \\ \text { AA } & 0.125 & 0.125 \\ \text { AB } & 0.375 & 0.125 \\ \text { AC } & 0.125 & 0.375 \\ \text { AD } & 0.375 & 0.375 \\ \text { BA } & 0.625 & 0.125 \\ \text { BB } & 0.875 & 0.125 \\ \text { BC } & 0.625 & 0.375 \\ \text { BD } & 0.875 & 0.375 \\ \text { CA } & 0.125 & 0.625 \\ \text { CB } & 0.375 & 0.625 \\ \text { CC } & 0.125 & 0.875 \\ \text { CD } & 0.375 & 0.875 \\ \text { DA } & 0.625 & 0.625 \\ \text { DB } & 0.875 & 0.625 \\ \text { DC } & 0.625 & 0.875 \\ \text { DD } & 0.875 & 0.875\end{array}$

Table 2: Accessions collected

\begin{tabular}{|c|c|c|}
\hline Scientific name & $\begin{array}{l}\begin{array}{l}\text { Arthurstone } \\
\text { and }\end{array} \\
\text { (Polokwane) } \\
\text { (Pars/Glenroy }\end{array}$ & Watershed \\
\hline Abelmoschus esculentus & 14 & 0 \\
\hline Alium cepa & 0 & 1 \\
\hline Amaranthus sp & 8 & 3 \\
\hline Arachis hypohaea & 18 & 0 \\
\hline Citrillus lanatus & 4 & 1 \\
\hline Cleome gynandra & 16 & 0 \\
\hline $\begin{array}{l}\text { Corchorus tridens and C } \\
\text { olitorius }\end{array}$ & 6 & 0 \\
\hline $\begin{array}{l}\begin{array}{l}\text { Cucurbita pepo and } \\
\text { maxima }\end{array} \\
\end{array}$ & 28 & 8 \\
\hline Ipomoea batatas & 1 & 0 \\
\hline Lagenaria siceraria & 2 & 1 \\
\hline Momordica sp & 7 & 0 \\
\hline Penisetum sp & 3 & 0 \\
\hline Phaseolus sp & 1 & 9 \\
\hline Sorghum bicolor & 0 & 2 \\
\hline Vigna subterranea & 17 & 1 \\
\hline \multicolumn{2}{|c|}{ 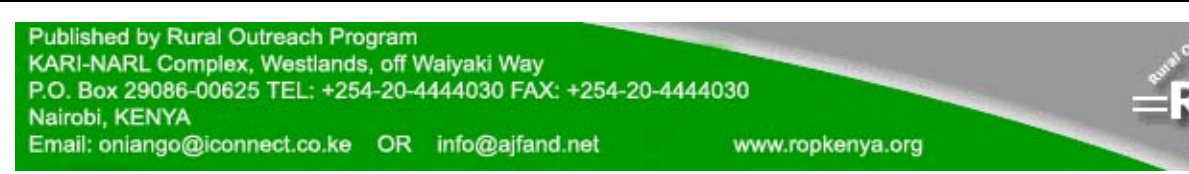 } & \\
\hline
\end{tabular}




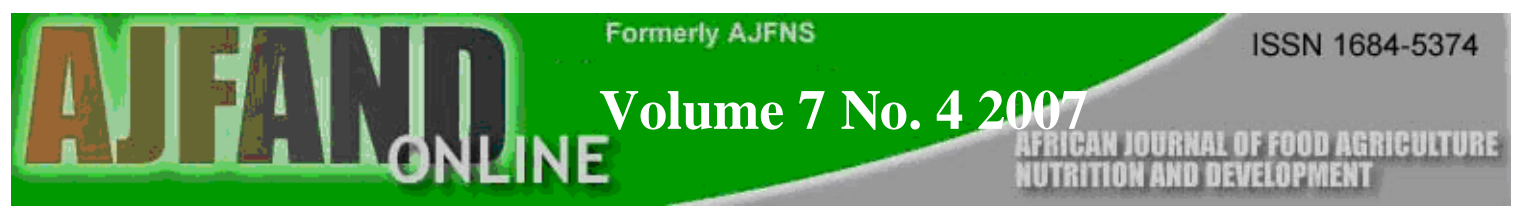

\begin{tabular}{|c|c|c|}
\hline Scientific name & $\begin{array}{l}\text { Arthurstone } \\
\text { and } \\
\begin{array}{l}\text { (Bushbuckridge) } \\
\text { (Polokwane) }\end{array} \\
\text { Mars/Glenroy } \\
\end{array}$ & Watershed \\
\hline Vigna unguiculata & 24 & 1 \\
\hline Zea maize & 28 & 5 \\
\hline Other sp & 16 & 0 \\
\hline Total & 193 & 32 \\
\hline
\end{tabular}




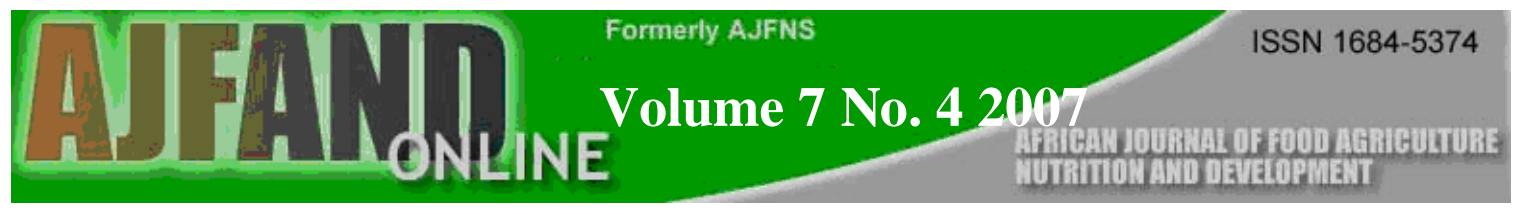

\section{REFERENCE}

1. Hijmans RJ Cruz M, Rojas E and L Guarino DIVA-GIS, version 1.4. A geographical information system for the analysis of biodiversity data. Manual. International Potato Centre, Lima, Peru. 2001.

2 Vorster HJ and WSJ van Rensburg "A tale of two villages and "Phara" lost and found!' International Plant Genetic Resources Institute Newsletter for sub-Saharan Africa, No. 20, December 2004. 